\title{
WOMEN'S EDUCATION IN A REFLECTION OF THE "HASNER ACT" AT THE END OF THE $19^{\mathrm{TH}}$ CENTURY
}

\section{Kaněčková Eva}

\begin{abstract}
The contribution deals with the issue of women's education in the context of the "Hasner Act". The objective of the paper is to outline the social discourse of the $19^{\text {th }}$ century and its impact upon the concept of subject matters and forms of women's education. The paper is focused on the representative case of higher women's education realized in the Institution of Earl Pötting in Olomouc, with tradition continuing up to this day.
\end{abstract}

\section{Key words}

Women's education, discourse of the $19^{\text {th }}$ century, higher women's education, Institution of Earl Pötting.

\section{Dívčí vzdělávání v odraze tzv. Hsnerova zákona na konci 19. století}

\section{Resumé}

Příspěvek se zabývá tematikou dícčího vzdělávání v kontextu tzv. Hasnerova zákona. Cílem je přibližit společenský diskurs 19. století a jeho dopad na pojetí obsahu a formy dívčího vzdělávání. V příspěvku se zabývám konkrétním př́ipadem vyšší dívčí školy v Olomouci, tzv. Ústav hr. Pöttinga, jehož tradice přetrvává do dnešní doby.

\section{Klíčová slova}

Dívčí vzdělávání, diskurs 19. století, vyšší dívčí škola, Ústav hr. Pottinga.

\section{Introduction}

The issue of female education has always stood side by side on the status and role of women in society. The social discourse of the $19^{\text {th }}$ century can be seen as a consequence of the so-called two-gender model in shaping the social 
meaning of gender roles. Due to the Enlightenment ideas in the late $18^{\text {th }}$ century, it begins to appear in the theory of the so-called natural order of sex, which created the ideal image of a pair as a true man and a true woman. The $19^{\text {th }}$ century fully perceived the definition of the female and male world and the public and private worlds. In the social construction of gender roles, there is a normative, moral and legal definition of gender roles in a different social mission and expectations.

The newly created social structure, of course, reflected also in the education of both the form and content of a particular goal. The division of spheres of public male and private female was also differentiated learning. Education became unnecessary for women, while for men it was a precondition for their professional and career development, and thus for increase of their social prestige. In education, this manifested in separation of education of girls and boys with a different conception of educational content. Even the introduction of compulsory education, by the so called Theresian Education Act, did not increase the number of girls in school classrooms, because girls were more useful and needed in the household. Only from the mid- $19^{\text {th }}$ century the ratio of men and girls began to be more balanced. ${ }^{1}$ It was largely due to changes in social thought, thanks to the emancipation movement to effect inter alia to improve girls' education. Hand in hand with the national movement women became a part of the public society. Their fraternal activities also helped them raise their own self-realization, which was a prerequisite for quality education. Already in the $19^{\text {th }}$ century there are attempts to encourage girls' education. An example is the activity of Bohuslava Rajská who opened her own institute for girls in order to educate patriotically-minded mothers and children in 1844. Further experiments are represented by the well-known Prague institute "Budeč ženský" founded by Karel Slavoj Amerling and managed by his wife, or the club "Slovanky" headed by Božena Němcová. ${ }^{2}$ Despite the fact that we can see the increasing interest in the establishment of schools for girls, the predominant form of girls' education was home education across the social spectrum. The higher social classes, especially citizens and aristocrats are frequently educated by home teachers; another evidence is the growing popularity of the so-called

\footnotetext{
${ }^{1}$ LENDEROVÁ, M. K hř́chu i $k$ modlitbě. Praha: Mladá fronta, 1999, p. 4. ISBN 80-2040737-5.

${ }^{2}$ KÁDNER, O. Vývoj a dnešní soustava školství. Praha: SPN, 1933, p. 281 (without ISBN).
} 
prescriptive literature as a guide to the domestic education of girls in home economics, moral principles and stereotypical notions of female destiny. ${ }^{3}$

Only since the second half of the $19^{\text {th }}$ century we are talking about the increase of institutionalized education of girls, what gradually leads to liberalization of learning content. It should also be noted that in society the idea conceived stereotypical ideal woman as wife, mother and housekeeper still dominated.

\section{2 "Hasner Act" 4 and girls' education}

With issuing of the Imperial Act of 1869, there were some changes that had considerable importance for the development of girls' education.

The first point was the extension of compulsory schooling by two years and the introduction of a common curriculum in general schools, where there was a merge of boys and girls' education. But it should be stressed that the then society did not welcome unified education. Despite the increased efforts of women's emancipation movement, the schooling of girls was still perceived as unnecessary and superfluous, since the fulfilment of their mission was in marriage and household. Under pressure of public opinion, girls' education was again weakened by the issue of education amendments in 1883 .

The second key point of the "Hasner Act" consisted in the introduction of public girls' teacher institute, which institutionalized this professional orientation for girls, while it was dominated by men by then. A year later the first public girls' "Pedagogium" was opened in Prague,. In the 90s, the number of public teaching institutions has grown considerably.

The third point, which helped girls' education expand, was an obligation to establish a network of city schools (at least one per district) to allow girls to achieve higher education. In other primary schools a Sunday course or courses started that have been guided by social needs; many of them were designed for girls and their education in the field of economics and family.

By the fourth point it was finally able to establish private teaching institutes. Thanks to the growing number of private schools there were more girls' schools in the school systems.

\footnotetext{
${ }^{3}$ The most favored authors were: Honoráta Zapová, Žofie Podlipská, Věnceslava Lužická, Marie Dobromila Rettigová. In LENDEROVÁ, M. K hř́chu i k modlitbě. Praha: Mladá fronta, 1999, pp. 50-51. ISBN 80-204-0737-5.

${ }^{4}$ In original: Imperial School Act no. 62, for simplification the deep-rooted name Hasner Act is used.
} 
As a result of changes in girls' education in the reflection of the "Hasner Act”, I would like to present the example of the private school for girls in Olomouc.

\section{Private Institute for Girls' Education of Earl Pötting in Olomouc}

The network of primary education in the Olomouc district was still in the late $19^{\text {th }}$ century, significantly enough, even though the "Hasner Act" made it mandatory to establish a municipal school within half a mile with a number exceeding 40 pupils/students. Here a great role was played also by a linguisticcultural determination of the population. The prevailing German part of the population was at the forefront of many provincial offices, including the Provincial School Board. This has deepened inequalities between the German and Czech education, although the "Hasner Act" allowed studies in all national languages. Problems of setting up schools became the main instrument of national struggles and enforcement of the Czech minority. In the district of Olomouc, the first Czech municipal school appeared in the early 1890s. In the late 1890s there was already the first girls' school in the near village of Loštice. ${ }^{5}$

In the radius of a nationalist group there was also a group of interested women. They believed that establishing more girls' schools acquired an important patron; it was the Count Potting Emanuel (1818-1898) ${ }^{6}$, whose national activities significantly contributed to the flowering of the Czech education in Olomouc. Following the example of women's associations, like the "Vesna" founded in Brno in 1870, in the early 1890s the Society of the Institute for Women was founded by the count Potting also in Olomouc; the Society was supported for example by Eliška Krásnohorská7. Thanks to the favourable political situation, the Minister of Education, the Count Gautsch (Minister in 1895-97) granted a permit to open private schools in Olomouc according to the application to the Federal Government.

The New Department of the count Potting, a Czech boarding house and school for the education of girls was opened in the new building on $15^{\text {th }}$ September, 1895. The main idea of the Institute met the contemporary concept of girls' education, a "well-educated housekeeper". The Institute was opened in three years, which were going in the girls' school curriculum. In addition the Institute provided a boarding house with dormitory. Financing of private

\footnotetext{
${ }^{5}$ More in FISCHER, R. České školství a matice školská v Olomouci II. Olomouc, 1937. p. 80 (without ISBN).

${ }^{6}$ Document fund M6-47. SOA in Olomouc.

${ }^{7}$ Document fund M6-47. SOA in Olomouc.
} 
schools was ensured by the Endowment Fund financed by the count Potting and a handful of patriotic patrons. Besides the contribution of bringing more girls into Czech schools in heavily German areas what has to be highlighted as well are other activities and educational support to the general public by means of evening courses at the Department of the Count Potting that got a considerable response. The courses offered attractions such as an Esperanto course, photography, models, dance and language courses of German and French and others.

The Department of the Count Potting worked under its status until 1901 and continued its tradition of girls' school of the Institute as the count Potting stated, which further expanded to a girls' higher school and girl' two-class business school. The tradition of girls' education has continued throughout the subsequent $20^{\text {th }}$ century up to today when the so-called Pöttingeum hosts a secondary school for nurses. ${ }^{8}$

\section{Conclusions}

Although in retrospect the social discourse of the $19^{\text {th }}$ century seems highly discriminatory against the status and role of women in society, we must consider the issue from the perspective of that time. The question of women's education is a very popular research topic for a number of feminist scholars; however, a very negative image can reduce the overall perception of the social structure of thought of that time. First was the question of universal schooling, which had already been outlined under Maria Theresa, but satisfactory results did not come even in the $19^{\text {th }}$ century. One of the reasons was the social change in society, in a broad context due to the decomposition of feudal relations with the newly perceived impact on the function and structure of the family. The working or public sphere was here for men, for women, the domestic or private domain. In this atmosphere there was also a shift in the structure of education. The question of female education became pointless because simply everything girls needed to learn they learned in the family (functional training); while boys were profiled in their future profession within school structures (intentional education).

The problem encountered throughout the $19^{\text {th }}$ century was to ensure institutional learning and the fulfilment of compulsory schooling. The only problem was the girls' secondary education, which the predominant part of society considered unnecessary. However, we note a progressive evolution since the second

${ }^{8}$ Document fund M6-47. SOA in Olomouc. 
half of the $19^{\text {th }}$ century as a result of the overall national movement, patriotism, club activities and related issues of female emancipation.

As a significant milestone in the education of girls can be seen a result of the "Hasner Act" at the end of the 1860s, which resulted in a growing network of both public and private schools especially for girls. The Act essentially provided the same general basis of education for girls and boys, which started a long way to equal access to education. A specific case law is the impact of establishment of the first girls' educational institute in the Olomouc district, and even in the Northern Moravia - the private Institute of the Count Potting (1895-1901) with the municipal school curriculum, although the mission was to train "educated housekeeper" in the Czech national spirit; on the other hand, it was a unique opportunity to acquire the necessary training with the possibility of economic independence from family or the possibility of further study.

\section{Bibliography}

FISCHER, R. České školství a matice školská v Olomouci II. Olomouc, 1937. p. 80 (without ISBN).

LENDEROVÁ, M. K hř́chu i k modlitbě. Praha: Mladá fronta, 1999, p. 4. ISBN 80-204-0737-5.

KÁDNER, O. Vývoj a dnešní soustava školství. Praha: SPN, 1933, p. 281 (without ISBN).

Document funds M6-47. SOA in Olomouc.

\section{Contact:}

Mgr. Eva Kaněčková,

Ústav pedagogiky a sociálních studií, PdF UP v Olomouci,

eva.kaneckovaeznam.cz 